\title{
Large-scale structural variation and long-term growth dynamics of Juniperus thurifera trees in a managed woodland in Soria, central Spain
}

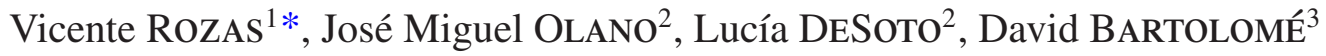 \\ ${ }^{1}$ Departamento de Ecología, CINAM de Lourizán, Apdo. 127, 36080 Pontevedra, Spain \\ ${ }^{2}$ Laboratorio de Botánica, EUI Agrarias, Los Pajaritos s/n, 42004 Soria, Spain \\ ${ }^{3}$ Cesefor, Polígono Industrial Las Casas, Calle C, Parcela 4, 42005 Soria, Spain
}

(Received 11 February 2008; accepted 19 August 2008)

\author{
Keywords: \\ browsing / \\ dendroecology / \\ growth release / \\ spanish juniper / \\ spatial autocorrelation / \\ traditional management
}

Mots-clés :

abroutissement /

dendroécologie /

reprises de croissance /

Juniperus thurifera / autocorrélation spatiale / gestion traditionnelle

\begin{abstract}
- Juniper woodlands have a great conservational and productive importance in Spain. However, basic traits of their structural variation and growth dynamics are unknown.

- To characterize the structural variation and assess both height and radial growth patterns, we sampled and measured stem cross-sections every $0.5 \mathrm{~m}$ in height from 107 Spanish juniper (Juniperus thurifera L.) trees, which were selected based on a $350 \mathrm{~m}$ regular grid over a whole woodland of 3300 ha in area. We used dendroecological techniques and spatial analysis to study tree structure and growth.

- Structural traits such as bole diameter and height were mainly determined by tree life-related parameters such as tree age and growth rate variation, while abiotic factors such as altitude played a minor role in determining structural variation. Over the last 300 years, juniper establishment has been continuous in time but discontinuous in space. Large-scale spatial heterogeneity of tree establishment, and the presence of an early growth suppression and abrupt growth changes in junipers $>100$ years old are consequences of an intense management that almost ceased in the late 19th century.

- Abrupt growth releases and suppressions were synchronic among different age classes, and coincided with documentary records on livestock decrease and key historical changes in land use. Growth patterns suggest that juniper is a browsing-tolerant species that is able to survive large periods of intense browsing pressure.
\end{abstract}

Résumé - Variation structurelle à grande échelle et dynamique de croissance à long terme de Juniperus thurifera dans des forêts aménagées à Soria dans le centre de l'Espagne.

- Les forêts de genévrier ont en Espagne une grande importance à la fois du point de vue de la conservation et de la production. Cependant, des caractéristiques de base de leur variation structurelle et leur dynamique de croissance sont inconnues.

- Pour caractériser la variation structurelle et évaluer à la fois la hauteur et les modèles de croissance radiale, nous avons échantillonné et mesuré les sections de troncs tous les $0,5 \mathrm{~m}$ en hauteur chez 107 genévriers (Juniperus thurifera L.), qui ont été choisis sur la base d'un réseau régulier de $350 \mathrm{~m}$ de côté dans la totalité d'un bois d'une surface de 3300 ha. Nous avons utilisé les techniques dendroécologiques et l'analyse spatiale pour étudier la structure des arbres et la croissance.

- Des caractéristiques structurales comme le diamètre de tronc et la hauteur ont été principalement déterminées par des paramètres concernant la vie de l'arbre comme l'âge et la variation du taux de croissance, tandis que des facteurs abiotiques comme l'altitude ont joué un rôle secondaire dans la détermination de la variation structurelle. Pendant les 300 dernières années, l'établissement du genévrier était continu dans le temps, mais discontinu dans l'espace. L'hétérogénéité spatiale à grande échelle de l'établissement des arbres, la présence d'une première suppression de croissance et des changements brusques de croissance chez des genévriers âgés de plus de 100 ans sont les conséquences d'une gestion intensive qui a presque cessé à la fin du $19^{\mathrm{e}}$ siècle.

\footnotetext{
* Corresponding author: vrozas.cifal@siam-cma.org
} 
- Des reprises brusques de croissance et des suppressions étaient synchrones parmi différentes classes d'âge et ont coïncidé avec des rapports documentaires sur la diminution du bétail, clefs des changements historiques dans l'utilisation de la terre. Les modèles de croissance suggèrent que le genévrier est une espèce tolérante à l'abroutissement et qui est capable de survivre à de grandes périodes d'abroutissement intense.

\section{INTRODUCTION}

Spanish juniper (Juniperus thurifera L., Cupressaceae) is a dioecious tree, endemic in southwestern Europe and Northern Africa, with the most significant populations distributed in central Spain and the Atlas mountains in Morocco (Blanco et al., 1997; Charco, 1999). This species covers over 125000 ha in the Iberian Peninsula, which represents $1 \%$ of the total forest surface in Spain (Blanco et al., 1997). Although this percentage is low, large juniper woodlands dominate the landscape in scarcely-populated mountain regions of the central Iberian Peninsula under a Mediterranean continental climate. Juniper woodlands have been traditionally managed as grazeable open systems combined with timber production for fire wood or construction.

To revitalize the local economy, regional authorities in Castilla y León are supporting initiatives for the commercialization of juniper wood for its industrial use as furniture or construction elements (Sanz et al., 2006). Concurrently, juniper woodlands are priority habitats for conservation in the European Community (European Commission, 1992). However, there is a lack of knowledge about the ecological and historical causes of the current structure and dynamics of juniper woodlands. This knowledge will be useful as a reference point to develop management policies that are focused on the conservation of Spanish juniper woodlands.

Recognition of the importance of human impacts is required in order to relate ecosystem dynamics to changes in management regimes or social patterns. Deep socioeconomic changes that have occurred in Europe since the middle of the 19th century caused a rural exodus and led to declines in traditional practices based on small-scale agriculture, pastoralism and use of forest resources (Thompson, 2005). In marginal mountain areas in southwestern Europe, these changes led to the expansion of shrublands and forests, and a decrease in semi-natural open habitats, which had previously been maintained by traditional practices (Chauchard et al., 2007). Apparently, land abandonment had a positive effect on Spanish juniper, with a significant increment in new regeneration and the expansion of its distribution area (Blanco et al., 1997). However, the cessation of traditional uses also had negative effects, such as an increase in shrub density and the potential replacement of juniper by more competitive tree species, such as oaks and pines (Gauquelin et al., 1999). Several studies performed in mountain areas of southern Europe, that combined historical and biological approaches, showed the correspondence between declines in local human populations, land-use transformations and changes in forest structure, growth and dynamics (Chauchard et al., 2007; Motta and Edouard, 2005; Motta et al., 2006).
We studied the large-scale structural variation and longterm growth dynamics of Juniperus thurifera, based on a regular sampling scheme along a 3300 ha managed juniper woodland in the Cabrejas del Pinar range, Soria. Greatest attention was given to the existence of differential age-specific growth patterns and to the spatial variation in juniper structure. The main objectives of this work were: (i) to characterize the structural variation and to identify the main tree life-related and environmental variables that shaped this juniper woodland, and (ii) to assess both height and radial growth patterns of junipers, the long-term variation in tree growth and their correspondence with past management changes.

\section{MATERIAL AND METHODS}

\subsection{Study area}

"El Enebral" common, a forested area of 3300 ha, is located near Cabrejas del Pinar, $35 \mathrm{~km}$ west of Soria in north-central Spain $\left(41^{\circ} 45^{\prime} \mathrm{N}, 02^{\circ} 05^{\prime} \mathrm{W}\right)$, with altitudes ranging between 1100 and $1330 \mathrm{~m}$. The climate is subhumid supramediterranean (RivasMartínez and Loidi, 1999) with a mean annual rainfall of $533 \mathrm{~mm}$, only $105 \mathrm{~mm}$ occurring during summer. Mean monthly temperature ranges from $2.8^{\circ} \mathrm{C}$ in January to $20.0{ }^{\circ} \mathrm{C}$ in July. The rock parent material is Cretaceous limestone, bearing calcium-rich, mainly shallow soils, with abundant areas of exposed bedrock covered with lichens and bryophytes.

The vegetation is open woodland dominated by Spanish juniper (90.4\% of total basal area) with some pines (Pinus pinaster Aiton and P. sylvestris L., $6.2 \%$ of total basal area) and holm oak (Quercus ilex L., $3.4 \%$ of total basal area). The woodland understorey and the open areas are covered by a variety of shrubs such as Arctostaphylos uva-ursi (L.) Sprengel., Cistus laurifolius L., Juniperus communis L., Lavandula latifolia Medicus, Satureja intricata Lange, and xeric grassland. The main traditional economic activities in this area are sheep and goat grazing, as well as timber extraction.

\subsection{Sampling}

The complete common was divided into squares of $350 \times 350 \mathrm{~m}$ following a regular grid. A circular plot of $32 \mathrm{~m}$ in diameter was established at every knot of this grid. In each plot, all trees more than $7.5 \mathrm{~cm}$ in DBH were identified to species and measured. Other field data registered at each plot were altitude, aspect, slope and the geographical coordinates of the central point. The juniper tree closest to the center, with DBH over $7.5 \mathrm{~cm}$, was felled and measured on the ground in 107 plots. Occasionally, the second or third tree nearest to the central point had to be selected, due to severe damage or hollowing of the central one. Number of stems and sex were also registered. Stems felled were sawn every $50 \mathrm{~cm}$ to obtain a set of regularly spaced stem disks, starting at $30 \mathrm{~cm}$ above ground up to the crown, yielding a total of 1007 disks. 


\subsection{Sample processing}

Stem disks were air-dried, surfaced with a power plane and then manually polished with a series of successively finer grades of sandpaper until the xylem cellular structure was visible under magnification. To check for deviations in tree-ring counts from the actual age, one tree-ring series from every stem disk at $1.3 \mathrm{~m}$ height was dated following standard dendrochronological procedures (Stokes and Smiley, 1968). Eccentric and lobate growth and abrupt growth changes were found in most stem disks, aggravating tree-ring dating. However, locally false and missing rings were identified along the disk circumference, and consequently the dating was corrected.

Total ring widths were measured along the dated series to the nearest $0.001 \mathrm{~mm}$ using a Velmex sliding-stage micrometer interfaced with a computer. One single radius along a lobe with active growth in the sections taken at $130 \mathrm{~cm}$ was chosen as representative of individual tree growth, aiming to reduce the noise caused by the abundant partially missing rings due to wedging rings. The computer program COFECHA (Grissino-Mayer, 2001; Holmes, 1983) was used to detect dating and measurement errors. Total tree age was estimated as the number of rings counted in the disk taken at $30 \mathrm{~cm}$ above ground. This procedure underestimates actual tree ages and the magnitude of underestimation was probably age-dependent because of historical variations in height growth rates (Palik and Pregitzer, 1995). For the interpretation of the results, it should be taken into account that tree ages were underestimated by between 4 and 15 years on average (Olano et al., 2008).

\subsection{Population structure and height growth analysis}

To assess the dependency of tree structural variables on individual and plot factors, we performed a regression of juniper DBH and height on individual tree variables (age, number of stems, sex, presence of past suppression and canopy position) and plot environmental variables (altitude, slope, aspect and plot basal area). Multiple regressions were performed by a forward stepwise procedure, and the best adjustments were obtained by a least-squares method (Sokal and Rohlf, 1995). All statistical analyses were performed using the SPSS v.14.0 package.

To differentiate growth patterns related to age, sampled trees were classified into five age classes: $<100$ years, 101-150 years, 151-200 years, 201-250 years and $>250$ years. Height growth patterns were calculated as the mean height growth curves for each age class. The ages at the different heights were estimated by ring counting at regular intervals of $50 \mathrm{~cm}$. According to the observed deviations between tree-ring counts and actual number of rings determined by cross-dating on the measured tree-ring series, ring counting has a mean accuracy of $\pm 2.7 \%$ of all tree rings. Mean height growth rates were compared among age classes, at three height intervals, by oneway ANOVA after testing for variance homogeneity with Levene's test, using Tukey's HSD method as a post hoc test.

We examined height growth trends by plotting height against age, considering the $30 \mathrm{~cm}$ high stem disk as age zero (Gamache and Payette, 2004). We performed a regression of height against age for the complete period in the non-suppressed junipers, and for the linear post-suppression period in the suppressed trees. Linear models showed the best fits in all cases, so we used the regression slope as an estimate of height growth rate. According to the observed patterns, we considered a suppression period as having height growth rates lower than $70 \%$ of the average growth rate. The dynamics of suppression events was characterized with regard to the duration of suppression periods, the year in which the suppression ended, and the height of the suppression end. These parameters were not gathered with annual resolution and therefore they underestimated the exact date of height growth release since they derived from stem disks that were taken every $50 \mathrm{~cm}$ along the stem.

To know whether previous suppression events could be recognized by plot traits (altitude, aspect, slope), tree structure (DBH, height, age, number of stems, sex) and growth (slope of height growth, mean radial growth rates of the most recent 50 years) at subsequent life stages we used logistic regression analysis. The model was depicted by $P=1 /\left(1+\mathrm{e}^{a+\Sigma b i X i}\right)$, where $P$ is the probability of an initial growth suppression for a tree $(P=0$ indicates non-suppressed tree, $P=1$ indicates suppressed tree), $a$ is the constant of the model and $b$ i are the coefficients for the independent variables $X \mathrm{i}$. Logistic regression was performed by a forward stepwise procedure and the best adjustment was obtained by a maximum-likelihood method (Sokal and Rohlf, 1995).

\subsection{Radial growth analysis}

We calculated tree-ring chronologies for the different age classes to empirically quantify low-frequency radial growth patterns. Raw ring widths were divided by the mean ring width of each series, which resulted in standardized but undetrended series. Single series were averaged to chronologies by an unweighted mean. This procedure preserves the complete information contained in tree rings, including both long-term age trends and abrupt growth changes (Veblen et al., 1991). Chronology calculation was done with the program ARSTAN (Cook and Holmes, 1996) and the variability in mean values was assessed by the annual standard deviation. Similarities among the undetrended tree-ring chronologies of different age classes were examined through correlation analysis during the common period of overlap.

To identify abrupt and sustained radial growth releases and suppressions affecting junipers, we examined the tree-ring patterns of all sampled trees on stem disks at $1.30 \mathrm{~m}$ above ground. The percentage growth change (PGC) filter of Nowacki and Abrams (1997) was applied to identify growth releases: $\mathrm{PGCr}=[(\mathrm{M} 2-\mathrm{M} 1) / \mathrm{M} 1] \times 100$, and suppressions: PGCs $=[(\mathrm{M} 1-\mathrm{M} 2) / \mathrm{M} 2] \times 100$, where M1 and M2 are, respectively, the preceding and subsequent 10-year ring-width means (Rozas, 2004). Individual PGC chronologies were calculated by applying these formulae to the individual tree-ring series. Mean PGC chronologies for each age class were obtained by classifying the individual PGC chronologies by age classes and averaging them. Episodes of abrupt and sustained growth releases and suppressions were recognized as peaks $>50 \%$ in the average PGC chronologies.

\subsection{Spatial analysis}

We checked for the presence of spatial patterns in juniper structural traits and growth by using Moran's I coefficient and kriging (Legendre and Fortin, 1989). Moran's I measures the autocorrelation within a quantitative variable for all pairs of points separated by a given spatial lag. Spatial autocorrelation is capable of revealing scales of forest structure, which are related to the size and distribution of tree patches (Biondi et al., 1994; Kuuluvainen et al., 1998). The hypothesis of spatial independence of tree structural traits in the complete woodland was tested on correlograms of the standard normal deviates (SND) of $I$ coefficients. The coefficients were calculated 

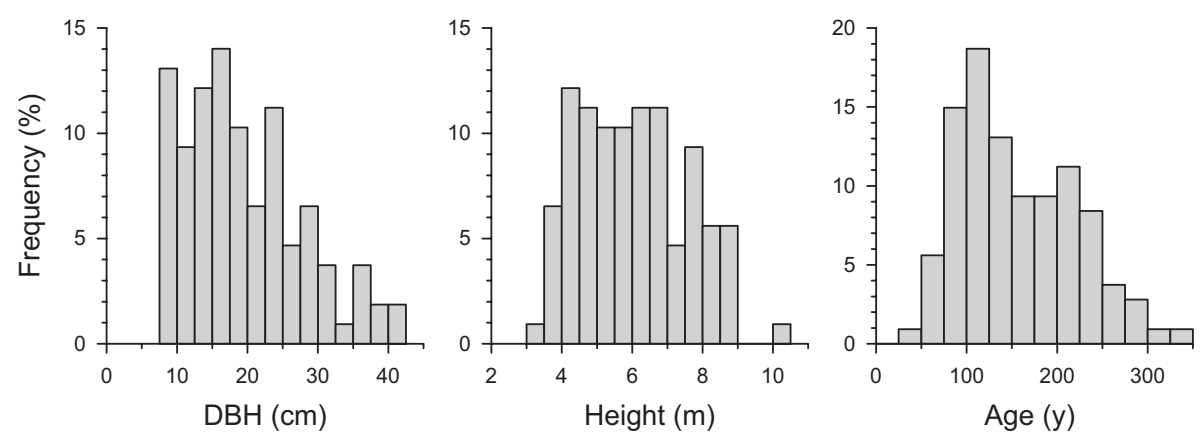

Figure 1. Frequency distributions of bole diameter at breast height $(\mathrm{DBH})$ at $1.3 \mathrm{~m}$ above ground, total height and juniper ages estimated at $30 \mathrm{~cm}$ above ground in Cabrejas.

by $500 \mathrm{~m}$ distance classes, up to inter-tree distances of $8000 \mathrm{~m}$, and checked against the critical values for a standard normal distribution. SND values above 1.96 indicate significant positive autocorrelation at $P<0.05$; values below -1.96 indicate significant negative autocorrelation. Only distance classes with at least 20 pairs of points were considered in the analyses. Since $I$ coefficients were calculated for several distance classes, each correlogram was considered statistically significant only if at least one SND value was significant at a Bonferroni-corrected significance level, $P=0.05 / n$, being $n$ the number of distance classes analyzed (Legendre and Fortin, 1989).

\section{RESULTS}

\subsection{Structural variation}

Maximum DBH for junipers was $40 \mathrm{~cm}$ with a monotonic downward distribution (Fig. 1). The highest trees reached $10 \mathrm{~m}$, with a dominance of trees between 4 and $8 \mathrm{~m}$. Age ranged from 25 to 350 years with an uninterrupted distribution through time, suggesting that regeneration has been continuous for the last 300 years, although a maximum in tree establishment was observed between 75 and 150 years ago.

Isoline maps and correlograms for DBH and height showed similar patterns (Fig. 2) with a structure in even-sized patches, as revealed by significant positive autocorrelation between neighboring plots $(500-1500 \mathrm{~m}$ for DBH, $0-1500 \mathrm{~m}$ for height), negative autocorrelations at intermediate distances (2500-5500 m) and again positive correlations at long distances $(7000-8000 \mathrm{~m})$. The affinity in the spatial structure of DBH and height would be a consequence of the allometric relationship between both variables (least-squares power regression: height $=1.760 \mathrm{DBH}^{0.416} ; R^{2}=0.50 ; N=107$; $P<0.001)$. Isoline maps and correlograms for age also revealed a spatial patchiness (Fig. 2). However, the size of evenaged patches was smaller than that of even-sized ones, with over $1000 \mathrm{~m}$ separated by $2000-3000 \mathrm{~m}$, as revealed by the alternatively positive and negative autocorrelation at more or less regular intervals of $1000 \mathrm{~m}$. Basal area also showed positive spatial correlation at short distances, up to $1000 \mathrm{~m}$, but without further significant patterns on a larger scale.

Juniper DBH was directly related to age (32.5\% of variance explained) and mean radial growth rate during the last 50 years
$(12.8 \%)$ according to the regression $\operatorname{model}\left(R_{a}^{2}=0.56, F_{4,83}=\right.$ 28.32, $P<0.0001)$; the model also included the presence of height suppressions with negative effect $(6.6 \%)$ and the slope of height growth with positive effect $(3.8 \%)$. The model for height was also highly significant $\left(R_{a}^{2}=0.40, F_{4,83}=15.54\right.$, $P<0.0001)$ and included the slope of height growth $(19.5 \%$ of variance explained) and the age of trees (11.8\%) as direct determinants of juniper height, while the presence of height suppressions $(6.1 \%)$ and plot altitude (2.6\%) showed negative effects on height.

\subsection{Height growth patterns}

Mean height growth curves greatly differed among age classes, suggesting that factors regulating height growth exhibited a historical trend in this woodland. A linear height growth pattern was observed in $70 \%$ of the trees. The remaining $30 \%$ had an early period of suppressed growth followed by a linear trend after height growth release. Older trees displayed a slow initial height growth followed by a sharp increase in the elongation rate (Fig. 3). Fifty-eight percent of the trees older than 150 years and $83 \%$ of the trees older than 200 years showed a release in height growth at the height of $2.5 \mathrm{~m}$ or lower. By contrast, trees younger than 100 years showed almost linear height growth patterns that were sustained during the complete lifespan. Mean rates of height growth of junipers younger than 150 years were significantly larger than those of junipers older than 200 years up to $180 \mathrm{~cm}$ high and also larger than junipers older than 250 years up to $380 \mathrm{~cm}$ (Tab. I). However, no significant differences in height growth rates were found among age classes from $430 \mathrm{~cm}$ high upwards. Correlograms of juniper height growth rates displayed no significant autocorrelation along the complete woodland, suggesting that height growth dynamics did not have a definite spatial pattern (results not shown).

The age of trees with an early period of height growth suppression ranged from 126 to 331 years and suppressions occurred at heights below $230 \mathrm{~cm}$ (Fig. 4A), with an average of $120.6 \mathrm{~cm}$. Most of these early suppressions ended between 1848 and 1916 (Fig. 4B), lasting for 37-199 years (Fig. 4D). Variables defining early suppression periods were related to tree age. Older trees experienced suppression up to higher 

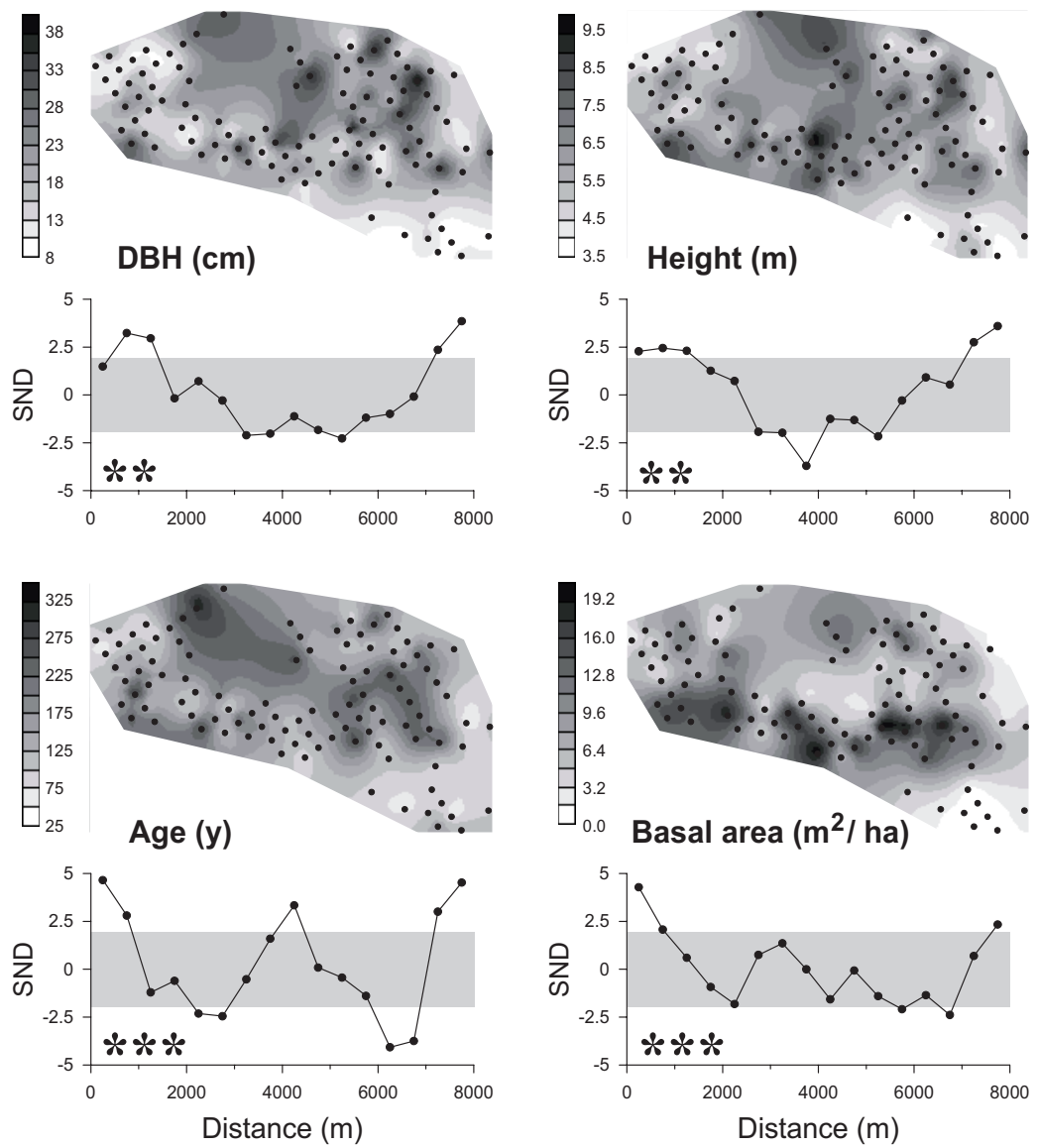

Figure 2. Spatial pattern of the structural traits DBH, height, age and basal area in Cabrejas woodland. Isoline maps obtained by kriging and the correlograms of standard normal deviates (SND) of Moran's I coefficients for $500 \mathrm{~m}$ distance classes are shown. Dots in the maps represent the sampled trees. SND values above or below the shaded area in the correlograms indicate significant autocorrelation $(P<0.05)$, positive or negative, respectively. The overall significance of correlograms is shown $\left({ }^{* *} P<0.01 ;{ }^{* * *} P<0.001\right)$.

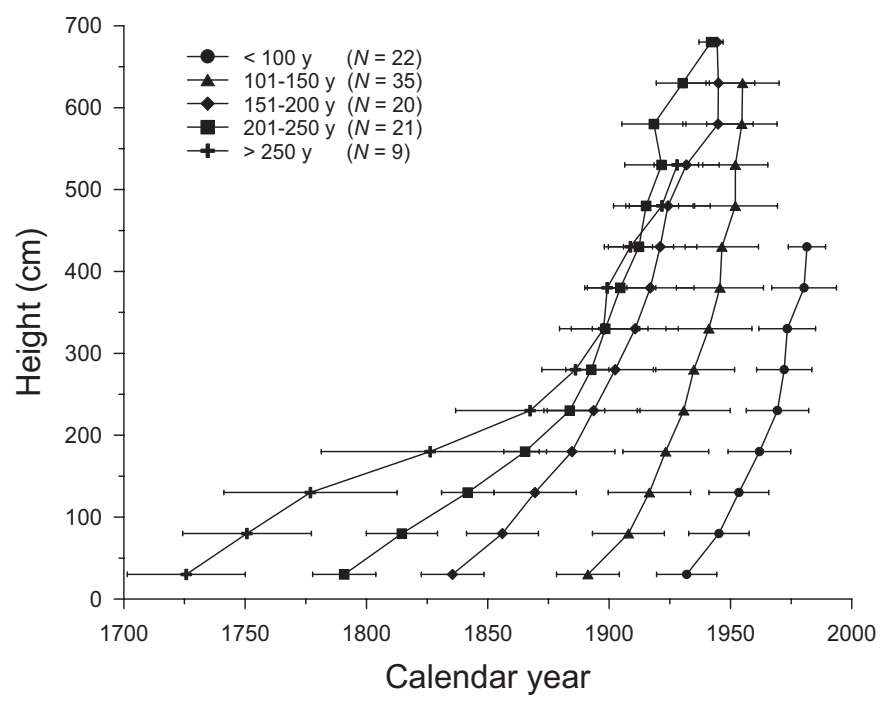

Figure 3. Mean height growth curves for juniper trees classified into five age classes. The curves represent mean years $( \pm$ SD) at which the heights indicated are reached at regular height intervals of $50 \mathrm{~cm}$. Only heights with at least five trees are shown. heights (Fig. 4A) and for longer periods (Fig. 4D), while the date of suppression end displayed an inverse relationship with tree age (Fig. 4B). The heights of suppression end and suppression duration were also positively correlated (Fig. 4E). However, the year of suppression end was not correlated with either the height of suppression end (Fig. 4C) or the suppression duration (Fig. 4F).

The logistic model for growth suppression was highly significant ( $\left.\chi^{2}=88.85, d f=4, P<0.0001\right)$ and showed a high predictive capacity, with $95.45 \%$ of the trees properly classified by the model. According to the logistic model, the investigated environmental variables were not able to predict tree height suppression. However, the presence of a past suppression event was positively related to tree age and an early suppression resulted in subsequent larger height and diameter growth rates, but a smaller diameter.

\subsection{Radial growth patterns}

Correlations among chronologies showed that junipers younger than 100 years had a distinct growth pattern (Tab. II). 
Table I. Mean height growth rates $\left(\mathrm{cm} \mathrm{y}^{-1}\right)$ of the five age classes compared by means of one-way ANOVA at three height intervals. Different letters in a row indicate significant $(P<0.05)$ differences between means according to post hoc HSD Tukey's test.

\begin{tabular}{lcccccccc}
\hline Height intervals & $F$ & d.f. & $P$ & $<100 \mathrm{y}$ & $101-150 \mathrm{y}$ & $151-200 \mathrm{y}$ & $201-250 \mathrm{y}$ & $>250 \mathrm{y}$ \\
\hline $30-180 \mathrm{~cm}$ & 9.99 & 4,97 & $<0.001$ & $6.54 \mathrm{a}$ & $6.55 \mathrm{a}$ & $5.24 \mathrm{ab}$ & $2.36 \mathrm{bc}$ & $1.89 \mathrm{c}$ \\
$230-380 \mathrm{~cm}$ & 2.99 & 4,90 & 0.023 & $9.00 \mathrm{a}$ & $9.01 \mathrm{a}$ & $7.27 \mathrm{ab}$ & $7.73 \mathrm{ab}$ & $4.69 \mathrm{~b}$ \\
$430-580 \mathrm{~cm}$ & 1.75 & 3,42 & 0.350 & & 8.24 & 5.76 & 6.43 & 4.48 \\
\hline
\end{tabular}

d.f.: Degrees of freedom.
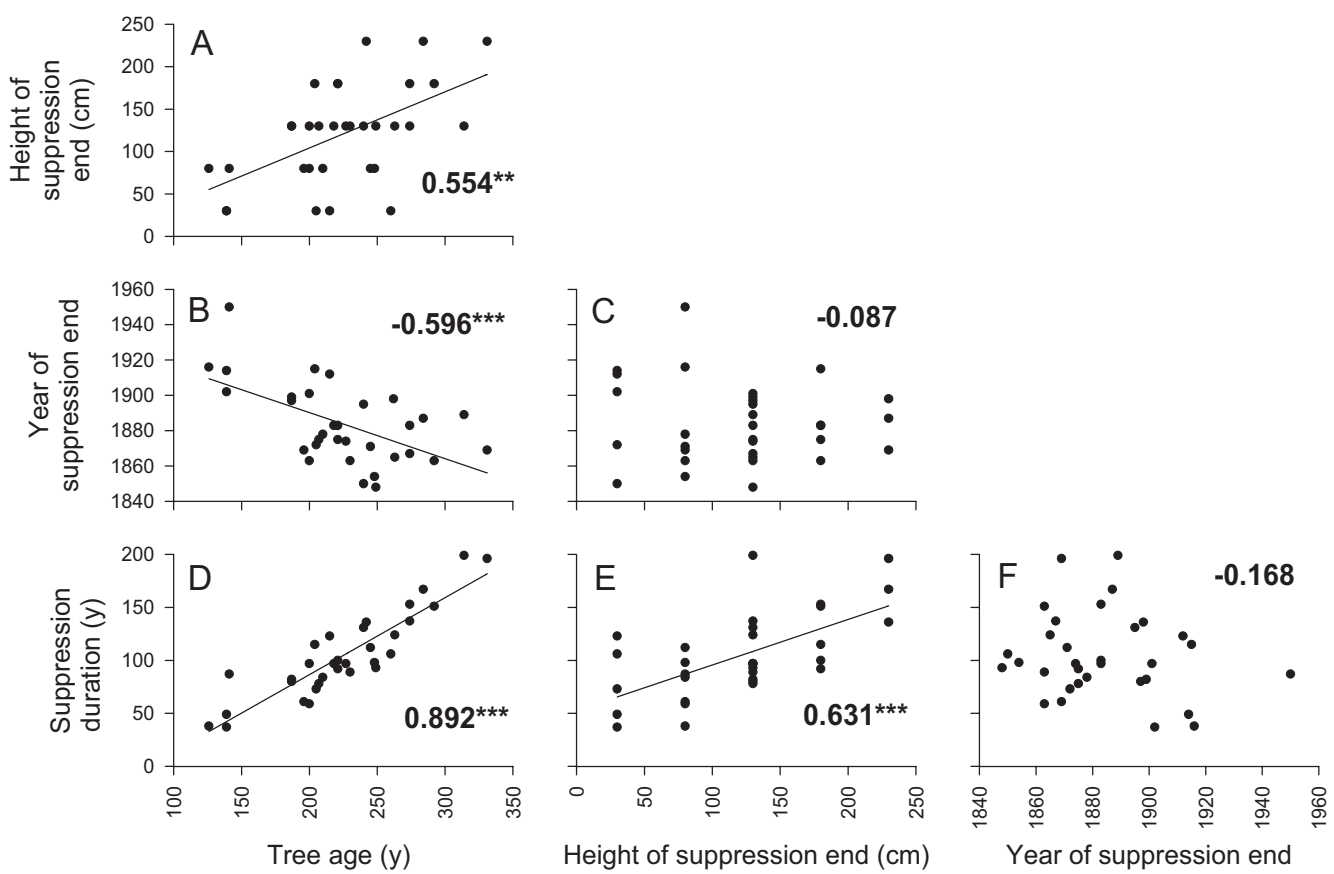

Figure 4. Relationships between tree age, height of suppression end, year of suppression end and duration of early height suppressions in suppressed junipers. Dates of tree age and height growth release are underestimates of the actual dates, since tree-ring series were obtained at a higher level than those at which the trees germinated and released. The correlation coefficients for the linear relationships, their significance, and the significant linear relationships, are shown. ${ }^{* *} P<0.01 ;{ }^{* * *} P<0.001 . N=32$ in all cases.

By contrast, trees older than 100 years shared a common growth pattern, with a significant correlation among chronologies. Junipers younger than 100 years showed a rising growth trend since 1940, whereas those older than 100 years declined in the same period (Fig. 5). Several growth trends were common to different age classes: growth surges in 1880 for the trees older than 200 years, in 1900 for trees older than 150 years and in 1920 for trees older than 100 years. A previous growth surge in 1790-1840 was also evident in the trees older than 250 years.

Mean PGC chronologies revealed that abrupt changes during the 19th century were often age-specific (Fig. 6), such as the growth releases detected in $1800,1843,1858,1870,1883-$ 1885 and 1899-1900, and the suppressions in 1863 and 1875. Growth releases in 1922 and 1964 were also evident only in trees 101-150 years old and younger than 100 years, respectively. However, radial growth suppressions in 1936-1937 and 1957-59 were evident in junipers of a wide variety of ages older than 100 years.
Table II. Correlation matrix between the standardized undetrended tree-ring chronologies from junipers classified into five age classes, calculated in the common period 1941-2004.

\begin{tabular}{ccccc}
\hline Age class & $101-150 \mathrm{y}$ & $151-200 \mathrm{y}$ & $201-250 \mathrm{y}$ & $>250 \mathrm{y}$ \\
\hline$<100 \mathrm{y}$ & -0.056 & 0.137 & 0.054 & 0.087 \\
$101-150 \mathrm{y}$ & & $0.758^{* * *}$ & $0.894^{* * *}$ & $0.743^{* * *}$ \\
$151-200 \mathrm{y}$ & & & $0.868^{* * *}$ & $0.711^{* * *}$ \\
$201-250 \mathrm{y}$ & & & & $0.710^{* * *}$ \\
\hline
\end{tabular}

$N=64$ in all cases. ${ }^{* * *} P<0.001$.

\subsection{Correspondence between radial and height growth}

Tree age, altitude and plot basal area were negatively related to radial growth rate for the period 1955-2004, but radial growth rate and tree height were directly related (Tab. III). In individual height and radial growth patterns, a temporal lag between radial growth and height growth releases was found in 

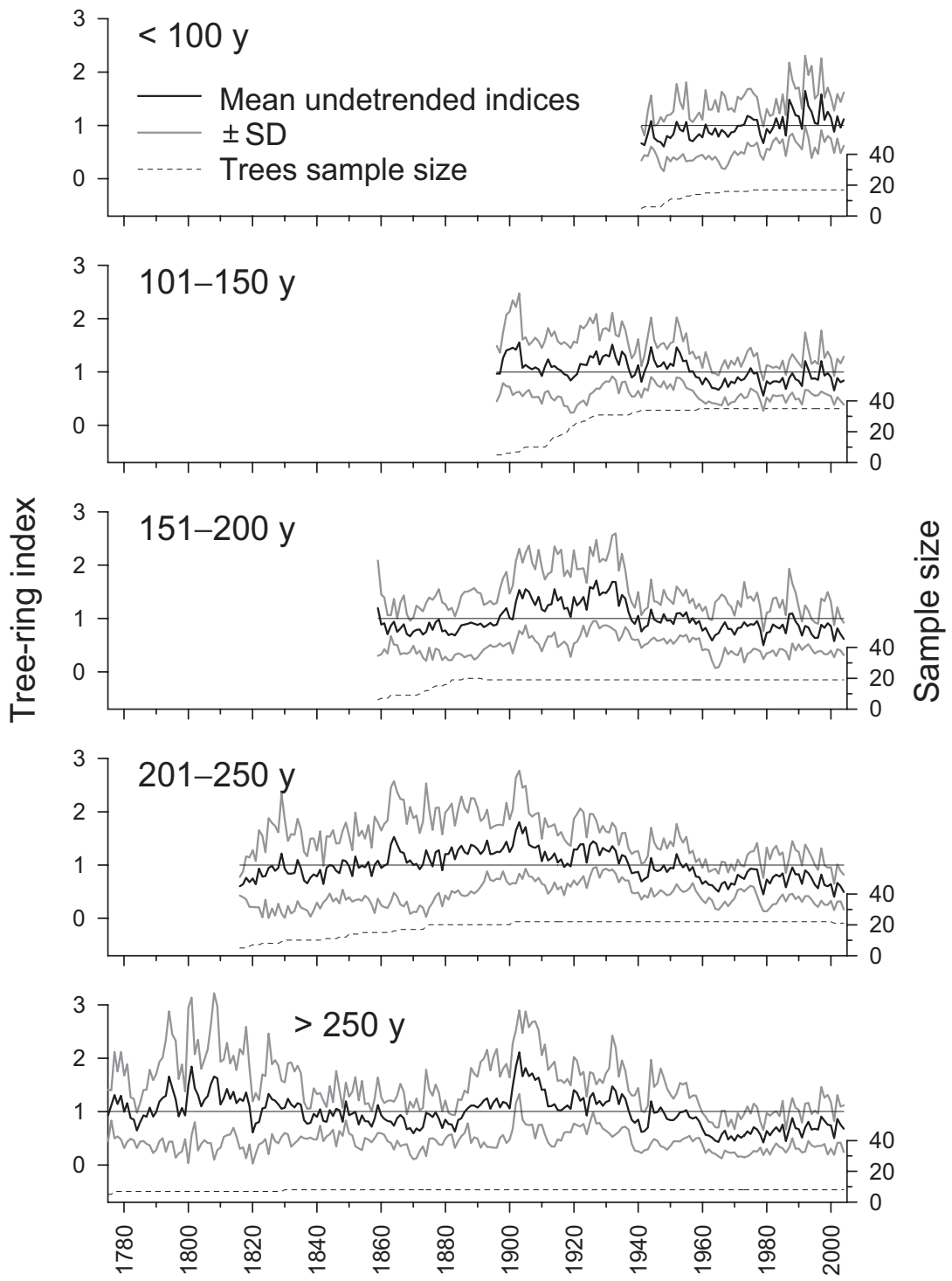

Figure 5. Mean standardized undetrended tree-ring chronologies for juniper trees classified into five age classes. Black lines represent the mean chronologies and gray lines their \pm SD intervals. The dashed lines indicate the temporal variation in the sample size. Only periods with at least five trees are shown.

all suppressed individuals having both types of releases. This lag varied between 4 and 47 years, being 17.7 years on average $(\mathrm{SD}=11.2, N=27)$. Lag duration was directly related to the year of radial release $\left(R_{a}^{2}=0.30 ; F_{1,25}=10.94 ; P=0.003\right)$, i.e., the more recent the release, the wider the lag between radial and height growth releases. Hence, a historical trend was evident in the lag between radial and height growth releases. However, lag duration was independent of any other individual or environmental variable.

\section{DISCUSSION}

\subsection{Age-dependent growth patterns}

The comparison of juniper growth patterns among the different age classes suggests that the factors that control both height and radial growth in Cabrejas have shifted during the past three centuries. Height growth patterns showed age dependency with an initial period of suppression in trees older than 150 years, but not in trees younger than 100 years. Agedependent height growth rates are common for tree species in dense forests, in which new cohorts of trees establish under a canopy of dominant trees, with smaller height growth rates in the understorey (Gutsell and Johnson, 2002). Age dependency in height growth patterns was also observed in Picea mariana in the taiga-tundra ecotone, with a recent release in height growth of younger trees probably related to the augmentation of mean temperature in the northern Hemisphere since the "Little Ice Age" (Gamache and Payette, 2004; Vallée and Payette, 2004). However, canopy stratification or climate warming did not seem to be relevant in the differentiation of 
Table III. Regression models for mean radial growth rate in the period 1955-2004 obtained by linear multiple regression. The percentage of variance explained, the coefficients, $t$ and $P$ values for variable selection, and the model statistics are shown.

\begin{tabular}{lccccc}
\hline Explanatory variable & \% Variance explained & Coefficient & $t$ & $P$ & Model statistics \\
\hline Age & 16.38 & -0.002 & -4.043 & 0.0001 & $R_{a}^{2}=0.31$ \\
Altitude & 5.32 & -0.001 & -2.579 & 0.0117 & 0.0025 \\
Plot basal area & 4.70 & -0.021 & -3.116 & $F_{4,83}=10.69$ \\
Height & 4.43 & 0.061 & 2.526 & 0.0134 & $P<0.0001$ \\
Constant & & 2.787 & 3.826 & 0.0003 \\
\hline
\end{tabular}

$R_{a}^{2}$ : Adjusted coefficient of determination.

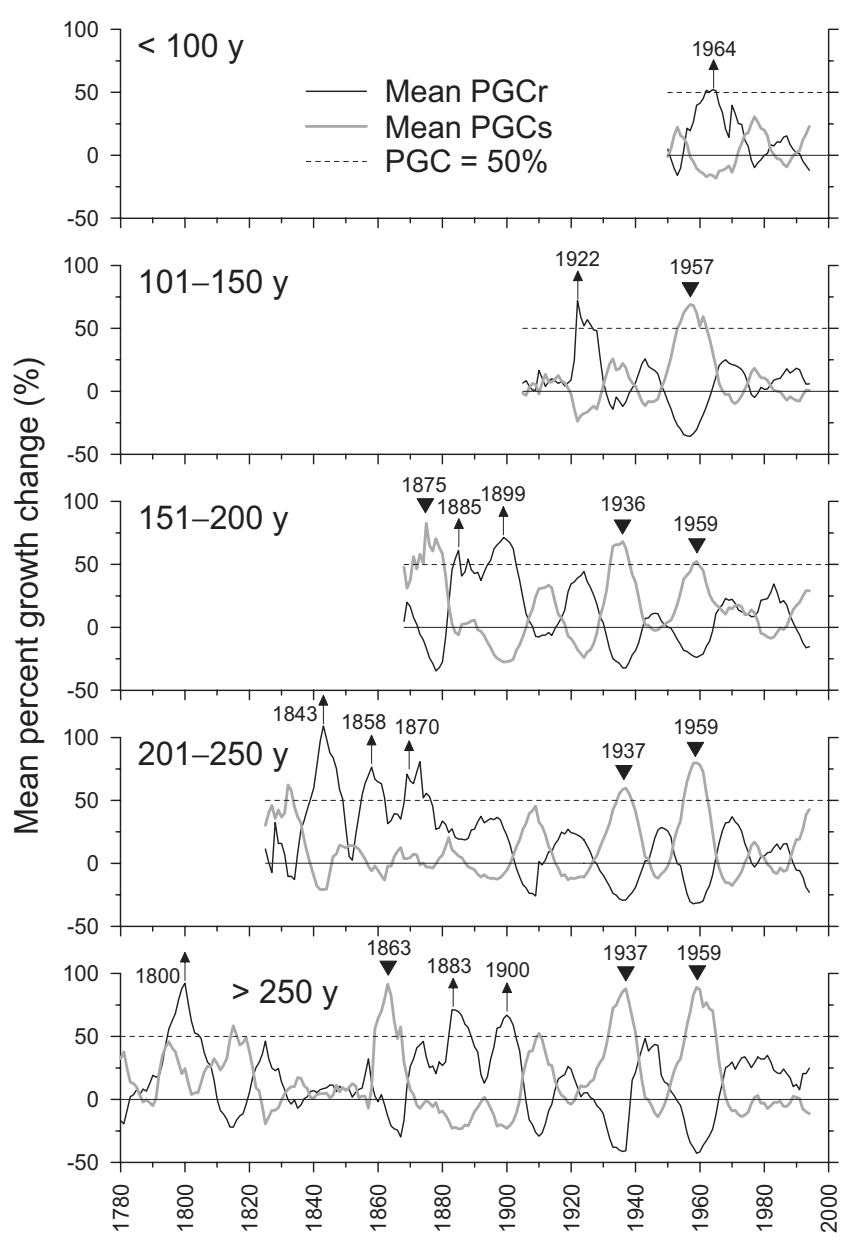

Figure 6. Mean percent growth change chronologies for juniper trees classified into five age classes. Black lines represent the chronologies for releases (PGCr) and gray lines for suppressions (PGCs). The dashed horizontal lines indicate the minimum threshold considered for event recognition $(\mathrm{PGC}=50 \%)$. Arrows indicate releases, triangles indicate suppressions. The temporal variation in tree sample size is shown in Figure 5.

height growth patterns among age classes in Cabrejas. Tree density in this woodland is too low (300 trees ha ${ }^{-1}$ on average) to establish a continuous canopy, and the woodland is not located near juniper latitudinal or altitudinal ecotones where growth would be at the limit due to climatic reasons. Early growth suppressions were restricted to low heights $(2.3 \mathrm{~m}$ maximum, $1.2 \mathrm{~m}$ on average), suggesting that ungulate browsing is the most plausible explanation for this pattern (Olano et al., 2008).

A negative impact of ungulate browsing on apical elongation has been observed for other tree species, with abruptly increasing height growth rates when the stem apex overgrew the browsing limit or ungulate density decreased (Motta, 2003; Ripple and Beschta, 2006; Vila et al., 2003). Although red and roe deer occur in the study area, large numbers of sheep and goats traditionally grazed extensively in Cabrejas woodland (with a maximum of over 500 goats and 2200 heads of sheep in 1850-1875; cf. historical archive from Soria province). Such herbivores can use junipers as a secondary resource in summer and winter when pastures are scarce or covered by snow, respectively (Bugalho and Milne, 2003; Zamora et al., 2001). Early suppressions in height growth became rare after the second half of the 19th century and almost disappeared in the 20th. Release from height suppressions was simultaneous with a general decrease in livestock that occurred in the 19th century in Spain (auction laws of 1837 and 1855; cf. Bauer, 1980) and in this area (G.E.H.R., 1991; Pérez-Romero, 1995).

Age-dependency in radial growth patterns was also consistent with the results. The correlations between undetrended chronologies and the sequences of abrupt growth changes indicated a particular pattern for trees younger than 100 years, and a more or less homogeneous pattern in those older than 100 years. Sampled junipers younger than 100 years were non-suppressed trees, although coetaneous suppressed individuals could remain as saplings that were not sampled because of their small size. Browsing pressure is nowadays considerably less intense than 100 years ago (G.E.H.R., 1991; Pérez-Romero, 1995), but many juniper saplings are suppressed individuals which are still browsed (unpublished data). These results show that junipers can remain suppressed during periods as long as two centuries; hence, the sampling bias toward non-suppressed trees could involve all age classes younger than 200 years. It still remains unclear why suppressions only affected some of the junipers; particularly if there is a trend of selective browsing on junipers by ungulates related to a combination of random and genetic factors, such as unequal plant accessibility, neighboring nurse plants and individual variation in plant defense against herbivory (Duncan et al., 2001; Smit et al., 2006; Vourc'h et al., 2002). 
Abrupt growth changes found in trees older than 100 years revealed particular adjustments in the management system that affected different age classes in different ways. Radial growth releases occurred in the late 19th century, related to the reductions in domestic ungulate densities (Bauer, 1980; G.E.H.R., 1991). Abrupt increases in radial growth have previously been observed in other tree species subjected to intense browsing pressure, after a drastic diminution in herbivore density (McLaren and Peterson, 1994; Vila et al., 2001). Radial growth releases derived from browsing escape usually follow a release in height growth when the main stem overcomes the browsing limit imposed by herbivores (Vila et al., 2003). As revealed in this work, the mean duration of the lag between radial growth releases and height growth releases was 17.7 years. Inter-tree variation in the duration of this lag is considerable, probably due to genetic differences, susceptibility to browsing and environmental variation (Vila et al., 2003).

Abrupt suppressions of radial growth in 1936-1937 and 1957-1959 can be directly attributed to massive branch pruning for winter fodder. The first period matches the start of the Spanish Civil War in 1936. The second one occurs just after the woodland was bought by the Cabrejas del Pinar municipality from private owners, and it was restored as a common. Pollarding of the intermediate branches in the trunk of junipers for winter fodder was a traditional practice in Spain (Blanco et al., 1997). Tree pollarding can be identified by abrupt decreases in radial growth due to the harsh removal of photosynthetic tissue (Rozas, 2004). Massive pruning of many junipers along the complete woodland may account for the synchronic growth reductions found in 1936 and 1957 in trees older than 100 years. Moreover, branch pruning may also be the reason for the abrupt growth reductions detected in 1863 and 1875 in the older junipers, but no historical sources documenting past land-use in these years have been obtained.

\subsection{Structural variation}

The spatial patterns of structural parameters indicated that trees of similar size cover wide areas in Cabrejas. The strong allometric relationship between tree DBH and height, and the relationship of both DBH and height to tree age, early suppression occurrence and the slope of height growth, could explain the great similarity in the spatial patterns of both parameters. The presence of a large-scale topographic pattern may explain the spatial structure of basal area in the woodland, with greater basal area on the broad south-facing slope than on the plateau. Environmental conditions on the plateau are characterized by poor and shallow soils, which could be the explanation for this pattern. In addition, the radial growth rate of junipers during the last 50 years was related to an ontogenetic factor (young trees grew faster than old trees) and an abiotic factor (slower radial growth at higher altitudes), but it also included biotic constraints (slower growth in greater plot basal area) and size dependency (tall trees grew faster than small trees).

Tree age at $30 \mathrm{~cm}$ indicated that juniper establishment in Cabrejas has been more or less regular during the past 300 years. In the interpretation of the results, it should be considered that the obtained distribution of tree ages is static, i.e. the trees that died over time were not taken into account. The age distributions also underestimate the representation of young individuals because trees smaller than $7.5 \mathrm{~cm}$ were not sampled. However, the results suggest that juniper age was spatially structured in clumps of smaller radius than for tree size. This pattern in juniper establishment could be a consequence of historical variations in browsing pressure at different sites. Grazing pressure has a great impact on seedling establishment, growth and survival, with these effects being intensified under restrictive conditions, as they occur in Mediterranean and mountain environments (Motta et al., 2006; Zamora et al., 2001). Long-term effects of grazing by domestic ungulates on extensive areas tend to be spatially heterogeneous (Dumont and Hill, 2001), and the spatial heterogeneity of grazing pressure would allow juniper establishment in the less intensively grazed areas, thereby creating a large-scale patchy structure of tree ages.

\section{CONCLUSION}

This retrospective study represents the first survey of structural traits and growth dynamics, based on dendroecological methods and spatial analysis, on the scale of a whole Spanish juniper woodland. Recruitment patterns have been continuous in time during the last 300 years, but clumped in space, with large patches of over $1000 \mathrm{~m}$ diameter consisting of individuals of similar age. The age-dependent growth patterns and the abrupt changes in growth of mature trees may be partially explained by the transformations of the traditional management system during the 19th and 20th centuries. Abrupt growth releases and suppressions were synchronic among different age classes, and coincided with documentary records on livestock decrease and key historical changes in land use. Particularly, junipers younger than 100 years grew without the intense browsing pressure which had been experienced by trees between 100 and 350 years old. Our results suggest that most junipers older than 100 years suffered from suppression periods with a duration of 50 to 200 years due to intense browsing pressure. We hypothesize that some juveniles are less susceptible to be eaten by ungulates than others, and that this differential susceptibility may be mediated by the shelter of nurse species in early stages, or by defensive traits probably related to the production of secondary chemical products. Nevertheless, the capability of this species to avoid herbivore damage using nurse plants and chemical defenses should be explored in further research.

Acknowledgements: The Agresta Company contributed data from field sampling. The town council of Cabrejas del Pinar, Soria, provided facilities during fieldwork. Felix Pinillos and Dori Sanz collaborated in the sampling design and Juan Carlos Rubio assisted us with stem disk preparation (Cesefor). Javier Muñoz and Ernesto López provided information on the management history. Ignacio GarcíaGonzález contributed the software for analysis of abrupt growth changes and improved an early version of the paper. Kenneth McKenney contributed English language assistance. Lucía DeSoto benefited from a Junta de Castilla y León grant and Vicente Rozas from an INIA-Xunta de Galicia contract. The Junta de Castilla y León partially funded this research with projects VA0110B05 and VA069A07. 


\section{REFERENCES}

Bauer E., 1980. Los montes de España en la historia. Ministerio de Agricultura, Servicio de Publicaciones Agrarias, Madrid.

Biondi F., Myers D.E., and Avery C.C., 1994. Geostatistically modeling stem size and increment in an old-growth forest. Can. J. For. Res. 24: 1354-1368.

Blanco E., Casado M.A., Costa M., Escribano R., García M., Génova M., Gómez A., Gómez F., Moreno J.C., Morla C., Regato P., and Sáinz H., 1997. Los Bosques Ibéricos: Una interpretación geobotánica. Planeta, Barcelona.

Bugalho M.N. and Milne J.A., 2003. The composition of the diet of red deer (Cervus elaphus) in a Mediterranean environment: a case of summer nutritional constraint? For. Ecol. Manage. 181: 23-29.

Charco J., 1999. El bosque mediterráneo en el norte de África. Agencia Española de Cooperación Internacional, Madrid.

Chauchard S., Carcaillet C., and Guibal F., 2007. Patterns of landuse abandonment control tree-recruitment and forest dynamics in Mediterranean mountains. Ecosystems 10: 936-948.

Cook E.R. and Holmes R.L., 1996. Guide for computer program ARSTAN. In: Grissino-Mayer H.D., Holmes R.L., and Fritts H.C. (Eds.), The International Tree-Ring Data Bank Program Library Version 2.0 User's Manual. Laboratory of Tree-Ring Research, University of Arizona, Tucson, pp. 75-87.

Dumont B. and Hill D.R.C., 2001. Multi-agent simulation of group foraging in sheep: effects of spatial memory, conspecific attraction and plot size. Ecol. Model. 141: 201-215.

Duncan A.J., Hartley S.E., Thurlow M., Young S., and Staines B.W., 2001. Clonal variation in monoterpene concentrations in Sitka spruce (Picea sitchensis) saplings and its effect on their susceptibility to browsing damage by red deer (Cervus elaphus). For. Ecol. Manage. 148: 259-269.

European Commission, 1992. Council directive 92/43/EEC of 21 May 1992 on the conservation of natural habitats and of wild fauna and flora. European Community, Brussels, Belgium.

Gamache I. and Payette S., 2004. Height growth response of tree line black spruce to recent climate warming across the forest-tundra of eastern Canada. J. Ecol. 92: 835-845.

Gauquelin T., Bertaudière V., Montès N., Badri W., and Asmodé J.F., 1999. Endangered stands of thuriferous juniper in the western Mediterranean basin: ecological status, conservation and management. Biodivers. Conserv. 8: 1479-1498.

G.E.H.R., 1991. Estadísticas históricas de producción agraria española 1895-1935. Ministerio de Agricultura, Pesca y Alimentación, Madrid.

Grissino-Mayer H.D., 2001. Evaluating crossdating accuracy: A manual and tutorial for the computer program COFECHA. Tree-Ring Res. 57: $205-221$.

Gutsell S.L. and Johnson E.A., 2002. Accurately ageing trees and examining their height-growth rates: implications for interpreting forest dynamics. J. Ecol. 90: 153-166.

Holmes R.L., 1983. Computer-assisted quality control in tree-ring dating and measurement. Tree-Ring Bull. 43: 69-78.

Kuuluvainen T., Järvinen E., Hokkanen T.J., Rouvinen S., and Heikkinen K., 1998. Structural heterogeneity and spatial autocorrelation in a natural mature Pinus sylvestris dominated forest. Ecography 21: $159-174$.

Legendre P. and Fortin M.-J., 1989. Spatial pattern and ecological analysis. Vegetatio 80: 107-138.

McLaren B.E. and Peterson R.O., 1994. Wolves, moose, and tree rings on Isle Royale. Science 266: 1555-1558.
Motta R., 2003. Ungulate impact on rowan (Sorbus aucuparia L.) and Norway spruce (Picea abies (L.) Karst.) height structure in mountain forests in the eastern Italian Alps. For. Ecol. Manage. 181: 139-150.

Motta R. and Edouard J.L., 2005. Stand structure and dynamics in a mixed and multilayered forest in the Upper Susa Valley, Piedmont, Italy. Can. J. For. Res. 35: 21-36.

Motta R., Morales M., and Nola P., 2006. Human land-use, forest dynamics and tree growth at the treeline in the Western Italian Alps. Ann. For. Sci. 63: 739-747.

Nowacki G.J. and Abrams M.D., 1997. Radial-growth averaging criteria for reconstructing disturbance histories from presettlement-origin oaks. Ecol. Monogr. 67: 225-249.

Olano J.M., Rozas V., Bartolomé D., and Sanz D., 2008. Effects of changes in traditional management on height and radial growth patterns in a Juniperus thurifera L. woodland. For. Ecol. Manage. 255: 506-512.

Palik B.J. and Pregitzer K.S., 1995. Variability in early height growth rate of forest trees: implications for retrospective studies of stand dynamics. Can. J. For. Res. 25: 767-776.

Pérez-Romero E., 1995. Patrimonios comunales, ganadería trashumante y sociedad en la tierra de Soria. Siglos XVIII-XIX. Consejería de Educación y Cultura, Junta de Castilla y León, Salamanca.

Ripple W.J. and Beschta R.L., 2006. Linking wolves to willows via risksensitive foraging by ungulates in the northern Yellowstone ecosystem. For. Ecol. Manage. 230: 96-106.

Rivas-Martínez S. and Loidi J., 1999. Bioclimatology of the Iberian Peninsula. Itinera Geobot. 13: 41-47.

Rozas V., 2004. A dendroecological reconstruction of age structure and past management in an old-growth pollarded parkland in northern Spain. For. Ecol. Manage. 195: 205-219.

Sanz A., Pinillos F., Lafuente E., Broto M., and Alcalde F., 2006. Aprovechamiento maderero de sabina en Castilla y León: Estudio de rendimientos en la fabricación de tarima de sabina. Actas del III Coloquio Internacional sobre sabinas y enebrales Tomo II. Junta de Castilla y León. Soria, pp. 395-403.

Smit C., Den Ouden J.A.N., and Muller-Scharer H., 2006. Unpalatable plants facilitate tree sapling survival in wooded pastures. J. Appl. Ecol. 43: 305-312.

Sokal R.R. and Rohlf F.J., 1995. Biometry: the principles and practice of statistics in biological research. 3rd ed. Freeman \& Co., New York.

Stokes M.A. and Smiley T.L., 1968. An introduction to tree-ring dating. University of Chicago Press, Chicago.

Thompson J., 2005. Plant Evolution in the Mediterranean. Oxford University Press, Oxford.

Vallée S. and Payette S., 2004. Contrasted growth of black spruce (Picea mariana) forest trees at treeline associated with climate change over the last 400 years. Arct. Antarct. Alp. Res. 36: 400-406.

Veblen T.T., Hadley K.S., Reid M.S. and Rebertus A.J., 1991. Methods of detecting past spruce beetle outbreaks in Rocky Mountain subalpine forests. Can. J. For. Res. 21: 242-254.

Vila B., Keller T., and Guibal F., 2001. Influence of browsing cessation on Picea sitchensis radial growth. Ann. For. Sci. 58: 853-859.

Vila B., Torre F., Guibal F., and Martin J.L., 2003. Growth change of young Picea sitchensis in response to deer browsing. For. Ecol. Manage. 180: 413-424.

Vourc'h G., Vila B., Gillon D., Escarré J., Guibal F., Fritz H., Clausen T.P., and Martín J.L., 2001. Disentangling the causes of damage variation by deer browsing on young Thuja plicata. Oikos 98: 271-283.

Zamora R., Gómez J.M., Hódar J.A., Castro J., and García D., 2001. Effect of browsing by ungulates on sapling growth of Scots pine in a Mediterranean environment: consequences for forest regeneration. For. Ecol. Manage. 144: 33-42. 